Serhii Chalyi, Volodymyr Leshchynskyi

Kharkiv National University of Radio Electronics, Kharkiv, Ukraine

\title{
HIERARCHICAL REPRESENTATION OF CAUSAL RELATIONSHIPS TO DETAIL EXPLANATIONS IN INTELLIGENT SYSTEMS
}

\begin{abstract}
The subject of research in the article is the processes of constructing explanations in intelligent systems based on the use of causal dependencies. The aim is to develop a hierarchical representation of causal relationships between the actions of an intelligent system to form an explanation of the process of the system's operation with a given degree of generalization or detailing. Representation of the hierarchy of cause-and-effect relationships allows you to form an explanation at a given level of detail using the input data in the form of a temporally ordered sequence of events reflecting the known actions of an intelligent system. Tasks: structuring the hierarchy of cause-and-effect relationships for known variants of the decision-making process in an intelligent information system, considering the temporal ordering of the corresponding actions; development of a model of a multi-level representation of causal dependencies for description for explanations in an intelligent system. The approaches used are: counterfactual analysis of causality, used to describe alternative dependencies for possible decision-making options; linear temporal logic to reflect the temporal aspect of causation. The following results were obtained. A generalized hierarchy of cause-and-effect relationships is highlighted for the known variants of the process of obtaining recommendations in an intelligent information system based on the temporal ordering of the corresponding decision-making actions. A model of hierarchical representation of causal dependencies has been developed to describe explanations in an intellectual system with a given degree of detail. Conclusions. The scientific novelty of the results obtained is as follows. A model of hierarchical representation of timeordered causal relationships is proposed to describe the explanations of the operation of an intelligent system with a given degree of detail. At the top level of the hierarchy, the model defines a generalized causal relationship between the event of using the input data and the event of the result of the system's operation. This connection describes the current task that the intelligent information system solves. At the lower level, cause-and-effect relationships are set between events sequential in time, between which there are no other events. At intermediate levels of the hierarchical representation, the causal dependencies of pairs of events are determined, between which there are other events. The developed model creates conditions for constructing explanations with a given degree of detailing of the actions of the decision-making process in an intelligent system. The model also provides the ability to describe early and late anticipation of alternative sequences of the decision-making process by describing causal dependencies for events between which there are other events.
\end{abstract}

Keywords: intellectual system, explanation, counterfactual analysis, causality, causation, temporal logic.

\section{Introduction}

The effectiveness of practical application of solutions that form intelligent systems is determined by the confidence of users in the results. The analysis of the mechanisms of perception of such results presented in [1] reflected the importance of developing explanations for the decision-making process, as modern intelligent systems have the form of a black box for the user [2]. The use of explanations provides greater trust of users, as well as the successful application of the recommendations [3].

To date, there are two alternative approaches to constructing explanations. The first involves the integration of the mechanism of explanations directly in the design of intelligent information system [1]. In this case, the principle of the white box is implemented, i.e. the process of obtaining a solution is interpreted directly within the intelligent system. The disadvantage of this approach is that the system must be designed with explanatory possibilities.

An alternative black box approach assumes that explanations are constructed on the basis of external causal relationships. Such dependencies are formed on the basis of known sequences of events that reflect the process of the intelligent system. Events are considered information about the actions performed by the intelligent system, user actions, and so on. The second approach is more flexible because it can be used to construct explanations for existing intelligent systems. For example, this approach provides complementary explanations to existing recommendation systems [4]. This indicates the relevance of the formalization of causal relationships to build explanations for the process of the intelligent system.

Existing approaches to constructing cause-andeffect relationships for constructing explanations are based primarily on work on counterfactual analysis [5-7]. This approach considers causality for the realized sequence of events in comparison with potentially possible but not realized sequences.

The counterfactual approach to the definition of causality is characterized by temporal asymmetry [4], which makes it possible to consider the temporal aspect and use the operators of temporal modal logic to formally describe the determined causal relationships [8]. Such dependencies play the role of constraints in the decisionmaking process. That is, they must be performed for all possible options for obtaining recommendations in the intelligent system [9].

In [10] it was shown that the causal relationship between events according to the counterfactual approach should consider the context of the decision-making process. This means that dependencies can be established with different levels of detail. This possibility of describing cause-and-effect relationships provides the creation of multilevel explanations, with details depending on the needs of the user [11].

However, existing approaches to the construction of the representation of causal relationships do not pay enough attention to the multilevel description of such 
dependencies. Therefore, building a hierarchy of causal relationships considering the temporal aspect is an important task, the solution of which makes it possible to adapt the explanation to the current requirements of the user.

The aim of the article is to develop a hierarchical representation of causal relationships between the actions of the intelligent system to form an explanation of the description of the process of the system with a given degree of generalization or detail.

Representation of the hierarchy of causation makes it possible to form an explanation at a given level of detail using input data in the form of a temporally ordered sequence of events that reflect the known actions of the intelligent system.

To achieve this goal the following tasks are solved:

- structuring the hierarchy of causal relationships for known variants of the decision-making process in an intelligent information system, considering the temporal ordering of relevant actions;

- development of a model of multilevel representation of causal dependences for description for explanations in the intelligent system.

\section{Structuring of the hierarchy of causal dependencies}

Counterfactual analysis of causal relationships requires the identification of actual events, as well as alternative events that cannot occur in this implementation of the decision-making process in the intelligent system. Since the decision-making process can be performed repeatedly, for each current implementation, alternative sequences of actions are such that "cannot occur" [7, 12, 13].

In fact, for each sequence of actions $D_{i}=\left\{d_{i, j}\right\}$ there is an alternative sequence $D_{l}, i \neq k$, which was implemented in the intelligent system. Therefore, when constructing causal relationships, it is necessary to consider all known options $D=\left\{D_{i}\right\}$ for the decisionmaking process. These sequences may contain different (or identical) causal relationships. Dependencies that are performed in all decision-making processes, form the basic sequence of actions common to all options for solving the problem in the intelligent system. Different dependencies form alternative sequences of actions. That is, on the set of sequences of actions $D$ there are common fragments that form the "skeleton" of the decision-making process. There are also different sequences of actions that form a variable part of the decision-making process.

- causal relationships that define explanations for typical sequences of actions for all variants of the decision-making process;

- dependencies that determine the differences between the options of the decision-making process.

The set of these dependencies forms a hierarchy, which makes it possible to gradually identify differences in the overall scheme of the decision-making process in the intelligent system. The most common causal relationship is the causal relationship between the first and last actions of the decision-making process. If the system solves different variants of the same problem, then the first and last action are similar or the same. For example, the first step is to process the input data, and the last is to present the solution to the user.

The most detailed causal relationships link actions $d_{i, j}$ and $d_{i, j+1}$, between which there are no other actions. That is, a detailed explanation of the decisionmaking process in the intelligent system can be formed on the basis of pairs of actions $\left(d_{i, j}, d_{i, j+1}\right)$, between which there is a causal connection. Such dependencies may differ for different implementation options of the decision-making process. For example, in the recommendation subsystem of the e-commerce system, additional steps can be taken when building recommendations if the user has installed filters on items of interest.

Intermediate levels of the description of causal dependencies can connect mainly sequences of actions between which other actions are carried out. In this first case, the key actions that are essential for constructing an explanation are highlighted. A causal link is established between these actions, which implicitly takes into account the intermediate causal links between the intermediate actions of the decision-making process. Additionally, sequences can be used $\left(d_{i, j}, d_{i, j+1}\right)$.

The hierarchy of causal dependencies, reflecting their presented details, is presented in the table. In general, this hierarchy contains causal dependencies, which are restrictions on the allowable sequence of actions for variants of the decision-making process, as well as dependencies that are performed for a subset of variants of this process.

\section{Probabilistic model of causation for counterfactual explanations in intelligent systems}

A counterfactual approach to the description of causality involves the selection of both the current causal relationship and alternatives to such relationships. Each current implementation of causal dependencies is reflected in the facts of the occurrence of individual pairs of events or sequences of such events that correspond to the actions of the decision-making process in the intelligent system [14].

That is, the description of the determined causal relationship within the counterfactual approach is given for the set $E$ of all known sequences of events $E_{i}$ that occurred during the formation of the solution in the intelligent system:

$$
E_{i}=\left\langle\begin{array}{c}
e_{i, 0}, e_{i, 1}, \ldots, e_{i, j}, e_{i, j+1}, \ldots, e_{i,\left|E_{i}\right|}: \\
w(\forall i \forall j) t_{i, j}<t_{i, j+1}
\end{array}\right\rangle,
$$

where $e_{i, j}$ - events that reflect the decision-making process in the intelligent system; each event has properties that reflect the state of the elements of such a system; $t_{i, j}$ - the time of occurrence of the event $e_{i, j}$. 
Table 1 - Hierarchy of causal dependencies

\begin{tabular}{|l|l|l|}
\hline \multicolumn{1}{|c|}{ Actions } & \multicolumn{1}{|c|}{ Level } & \multicolumn{1}{c|}{ Properties } \\
\hline $\begin{array}{l}\text { Relationship between the first and last action } \\
\text { of the decision-making process (for example, } \\
\text { between the processing of input data and the } \\
\text { presentation of the result to the user) }\end{array}$ & $\begin{array}{l}\text { The top level of the hierarchy, } \\
\text { without detailing the decision- } \\
\text { making process }\end{array}$ & $\begin{array}{l}\text { Limits the class of tasks that the } \\
\text { intelligent system solves }\end{array}$ \\
\hline $\begin{array}{l}\text { Relationship between actions with } \\
\text { intermediate actions (i.e. minor actions are } \\
\text { skipped) }\end{array}$ & $\begin{array}{l}\text { Intermediate levels, highlighting } \\
\text { the key steps of the decision- } \\
\text { making process }\end{array}$ & $\begin{array}{l}\text { Specifies a causal relationship that } \\
\text { displays the result of a sequence of } \\
\text { intermediate actions }\end{array}$ \\
\hline $\begin{array}{l}\text { The relationship between actions between } \\
\text { which there are no other actions }\end{array}$ & Lower & $\begin{array}{l}\text { Specifies a clear causal link between all } \\
\text { actions of the decision-making process }\end{array}$ \\
\hline
\end{tabular}

The sequence $E_{i}$ of events $e_{i, j}$ has the following properties:

- the order of events $e_{i, j}$ in time is determined by timestamps $t_{i, j}$;

- the initial event of the sequence $E_{i}$ reflects the execution of the operation or procedure of data entry for decision-making in the intelligent system;

- the final event $e_{i,\left|E_{i}\right|}$ reflects the fact of displaying the resulting decision of the intelligent system;

- event information is available directly when the user interacts with the intelligent system;

- event information can be obtained from logs or intelligent system databases.

Examples of such sequences are knowledgeintensive business process logs, records of user interaction with the referral system, and more.

Then deterministic causal relationships $c_{j, k}^{(n)}$ between events $e_{i, j}$ and $e_{i, j}$ arise if, after the first event in any sequence $E_{i}$, a second event always occurs due to $n$ intermediate events. If the first event $e_{i, j}$ is absent in at least one sequence, then the second event never occurs in this sequence.

According to (1), each event $e_{i, j}$ has a timestamp $t_{i, j}$. This property makes it possible to display a deterministic causal relationship $c_{j, k}^{(n)}$ using the modal temporal logic operators $\mathrm{X}(\mathrm{NeXt})$ and $\mathrm{F}$ (Future) as follows:

$$
\begin{gathered}
c_{j, k}^{(0)}=f_{i, j} X f_{i, k}, \\
c_{j, k}^{(n)}=f_{i, j} F f_{i, k}, n=\frac{1, \min \left(\left|E_{i}\right|\right)-1}{i},
\end{gathered}
$$

where $f_{i, j}, f_{i, k}$ - facts of occurrence of events $e_{i, j}$ and accordingly $e_{i, k} ; n$ - the number of facts of occurrence of intermediate events between events $e_{i, j}$ and $e_{i, k}$.

Every fact $f_{i, j}$ of occurrence of an event $e_{i, j}$ is true if the time of occurrence of this event is known $t_{i, j}$ :

$$
f_{i, j}=\text { true, iff } \exists i \exists j: t_{i, j} \neq 0 \text {. }
$$

The availability of information about the time of occurrence of events confirms the facts of their implementation.

Therefore, the use of this information is a necessary condition for determining the causal relationships according to the factual approach.

In expressions (2) and (3) logical variables of the facts $f_{i, j}, f_{i, k}$ of occurrence of events are used as events $e_{i, j}$ and $e_{i, k}$ are described by set of values of their properties directly. Each property of an event has a finite set of values. All possible property values can be obtained from logs or from the database of the intelligent system.

The number $n$ of intermediate event facts for expression (2) is 0 , because the temporal operator "NeXt" specifies a pair of consecutive facts.

That is, the event $e_{i, k}$ occurs immediately after the $e_{i, j}$ event.

The maximum number of facts of intermediate events when using the operator "Future" is determined by the length of the minimum sequence of events $E_{i}$. This limitation is due to the fact that the determined causal relationship must be performed on all sequences $E_{i}$. That is, the number of facts of intermediate events should be the same for everyone $E_{i}$.

Combining expressions (2) and (3) makes it possible to determine the existence of a causal relationship between events $e_{i, j}$ and $e_{i, k}$ so:

$$
(\forall i) \exists c_{j, k}^{(n)}: \exists\left(f_{i, j}, f_{i, k}\right): n=k-j-1 .
$$

Deterministic dependence (5) has the following properties:

- performed on all sequences of events $E_{i}$;

- the number of facts of intermediate events between $f_{i, j}, f_{i, k}$ is the same for all sequences $E_{i}$.

The latter characteristic is an additional limitation for the traditional counterfactual definition of causality [5]. However, it makes it possible to consider the choice of alternatives in the decision-making process, as well as cycles of actions to build such a decision. In particular, when choosing an alternative in the "If-Then" construct, the same events may occur sequentially, but the number of intermediate events will differ. This situation occurs after the event $e_{i, j}$ when choosing one of the 
alternatives, ancillary actions are performed that do not affect the final event $e_{i, k}$.

The causal relationship (5) between pairs of events makes it possible to determine the causal relationship of the species "The sequence of actions of the intelligent system -> resulting recommendation". The sequence of actions is displayed by a sequence of events $E_{i}$. Selecting a subset of the main events from this sequence makes it possible to describe causal dependencies with different degrees of detail by combining temporal operators $\mathrm{X}$ and F for temporal dependences (2) and (3). That is, the decision-making process can be represented as a hierarchy of subprocesses. Each of these subprocesses contains a subset of events at a given level of generalization.

The top-level dependence $c_{0, \text { fin }}^{(+)}$describes the causal relationship between the input data and the result obtained. Let the initial event $e_{i, 0}$ reflects the execution of the procedure of data entry into the intelligent system, and the latter $e_{i, f i n}-$ the output of the system. Then the dependence $c_{0, \text { fin }}^{(+)}$looks like:

$$
c_{0, \text { fin }}^{(+)}:(\forall i) f_{i, 0} F f_{i, f i n} .
$$

where $f_{i, 0}, f_{i, f i n}$. - the facts of the initial and final event of the sequence $E_{i}$; the "+" index specifies any number of intermediate facts $f_{i, j}$, as each sequence can have a different number of events.

For example, for a recommendation system in an ecommerce system, the top-level dependency that explains the recommendation may look like "For items with user-defined properties, the most popular products are < Product List >". For example, for a recommendation system in an e-commerce system, the top-level dependency that explains the recommendation may look like "For items with user-defined properties, the most popular products are <Product List $>$ ".

The causal relationship (6) describes all possible alternative sequences of the intelligent system, which lead to similar recommendations. Therefore, such dependence should be considered as a global constraint that specifies a typical subset of input parameters and the corresponding recommendation. For the above example of causal dependence in the e-commerce system, the user can select products of a certain category with a given set of properties (brand, price, etc.). The result is also products with a certain set of properties (in this example - the most popular products).

Then the causal relationship (6) will be executed only for the initial and final events of the given subsets $E_{0}$ and $E_{\text {fin }}$ accordingly:

$$
E_{0}=\left\{e_{i, 0}\right\}, E_{\text {fin }}=\left\{e_{i, f i n}\right\}:(\forall i) \exists E_{i} \in E .
$$

Dependence $c_{0, f i n}^{(+)}$is a constraint, i. e. it must be satisfied for all sequences from the set $E$ :

$$
\left(\forall E_{i} \in E\right) \exists c_{0, \text { fin }}^{(+)} .
$$

According to (7), the causal relationship (6) is determined only for a finite set of sequences $E$. Each sequence in this set uses similar input and solves the same problem. This approach makes it possible to generalize the actual sequence of events and construct causal relationships $c_{j, k}^{(n)}$. That is, we obtain deterministic dependences for all known options for forming a solution to a specific problem in an intelligent system. At the upper level of generalization, all these processes are one dependence $c_{0, \text { fin }}^{(+)}$. Dependencies are used at more detailed levels $c_{j, k}^{(+)}, c_{j, k}^{(n)}, c_{j, k}^{(0)}$.

Dependency $c_{j, k}^{(n)}$ actually sets implicit links between events that reflect identical sequences of actions for alternatives to the decision-making process:

$$
c_{0, f i n}^{(+)}=\wedge c_{j}^{(n)} \text {. }
$$

Dependence $c_{j, k}^{(0)}$ used at the level of maximum detail of the description of causal relationships, as it determines the explicit causal relationship for a pair of events that have occurred consistently in time:

$$
c_{j, k}^{(n)}=c_{j, j+1}^{(0)} \wedge c_{j+1, j+2}^{(0)} \wedge \ldots \wedge c_{k-1, k}^{(0)} .
$$

Accordingly, the upper level dependence can be represented as a sequence of detailed causal relationships:

$$
c_{0, f i n}^{(+)}=c_{1,2}^{(0)} \wedge c_{2,3}^{(0)} \wedge \ldots \wedge c_{\text {fin-1,fin }}^{(0)} .
$$

Thus, the model of the hierarchy of causal relationships contains causal relationships $c_{j, k}^{(n)}$ with varying degrees of detail in the decision-making process:

$$
M=\left\{\begin{array}{c}
c_{j, k}^{(n)}: n=\left\{\begin{array}{c}
+, 0,1, \ldots, \min \left(\left|E_{i}\right|\right)-1 \\
i
\end{array}\right\}, \\
j=0, \max _{i}\left(\left|E_{i}\right|\right)-1, k=1, \max \left(\left|E_{i}\right|\right), \\
i
\end{array}\right\} .
$$

Relationship between dependencies $c_{j, k}^{(n)}$ is given by expressions (8)-(10).

An important feature of this model is that it allows you to describe the early and late advance of events [4]. The essence of anticipation is to interrupt the main implementation of the decision-making process depending on the occurrence of events in the alternative implementation. Or an alternative implementation depending on the events in the main process. The description of the advance of events is carried out using the middle level of the hierarchy. To do this, dependencies $c_{j, k}^{(n)}$ are set for different alternatives, which in one case contain the main event, and in another - the overlapping event. 


\section{Conclusions}

A generalized hierarchy of causal relationships for known variants of the process of obtaining recommendations in the intelligent information system based on the temporal ordering of relevant decisionmaking actions is highlighted.

At the top level of this hierarchy is determined by the class of tasks that solve the intelligent information system. At the lower level, the causal relationships between the elementary actions of the decision-making process in such a system are set.

A model of multilevel representation of timeordered causal dependences is proposed to describe explanations of the operation of an intelligent system with a given degree of detail. The model considers the relationships between events that reflect the actions of the intelligent system. At the top level of the hierarchy, the model defines a generalized causal relationship between the event of the use of input data and the event of obtaining the result of the system. Top-level causal communication is a constraint that determines the task that an intelligent information system solves. The lower level describes the causal relationships between successive events over time, between which there are no other events. At intermediate levels of the hierarchical representation, causal relationships are determined for pairs of events, among which there are other events.

The developed model provides conditions for construction of explanations with the set degree of detailing of actions of process of decision-making in intelligent system.

The model also provides the ability to describe early and late anticipation for alternative sequences of the decision-making process by describing causal relationships for events that include other events.

\section{REFERENCES}

1. Miller T. (2019), "Explanation in artificial intelligence: Insights from the social sciences”, Artificial Intelligence, vol. 267, pp.1-38, DOI: https://doi.org/10.1016/j.artint.2018.07.007.

2. Castelvecchi D. (2016), “Can we open the black box of AI?” Nature, Vol. 538 (7623), pp. 20-23.

3. Arrieta B., Rodriguez N. and Del Ser J. (2020), "Explainable Artificial Intelligence (XAI): Concepts, Taxonomies, Opportunities and Challenges toward Responsible AI", Information Fusion, Vol 58, pp. 82-115. DOI: https://doi.org/10.1016/j.inffus.2019.12.012.

4. Chalyi S., Leshchynskyi V. and Leshchynska I. (2019), Designing explanations in the recommender systems based on the principle of a black box. Advanced information systems, Vol. 3, No 2, pp. 47-51. DOI: 10.20998/2522-9052.2019.2.08.

5. Lewis D. (1973), Causation. Journal of Philosophy. № 70 (17). P. 556-567.

6. Lewis D. (1979), Counterfactual Dependence and Time's Arrow. Counterfactuals and Laws. Vol. 13, №. 4. P. 455-476.

7. Lewis D. (2000), Causation as influence. Journal of Philosophy. Vol. 97, №. 4. P. 182-97.

8. Chalyi S., Leshchynskyi V. and Leshchynska I. (2019), Modeling explanations for the recommended list of items based on the temporal dimension of user choice. Control, navigation and communication systems, Vol. 6 (58), pp. 97-101. doi:https://doi.org/10.26906/SUNZ.2019.6.097.

9. Chalyi S., Leshchynskyi V. and Leshchynska I. (2019). Method of forming recommendations using temporal constraints in a situation of cyclic cold start of the recommender system. EUREKA: Physics and Engineering, 4, 34-40. DOI:10.21303/24614262.2019.00952.

10. Paul L. A. Aspect Causation. In Collins, Hall \& Paul. 2004. P. 205-24.

11. S. Chalyi, V. Leshchynskyi, I. Leshchynska (2020)? Multilevel personalization of explanations in recommender systemsAdvanced Information Systems.Vol. 4, No 2. - P. 170-175.

12. Halpern J. Y., Pearl J. (2005), Causes and explanations: A structural-model approach. Part I: Causes. The British Journal for the Philosophy of Science. Vol. 56 (4). P. 843-887.

13. Halpern J. Y., Pearl J. (2005), Causes and explanations: A structural-model approach. Part II: Explanations. The British Journal for the Philosophy of Science. Vol.56 (4). P. 889-911.

14. Chala O. (2019), Development of information technology for the automated construction and expansion of the temporal knowledge base in the tasks of supporting management decisions. Technology audit and production reserves. Vol. 1/2(45). P. 9-14. DOI: $10.15587 / 2312-8372.2019 .160205$.

Received (Надійшла) 11.10.2021

Accepted for publication (Прийнята до друку) 24.11.2021

\section{ВідомОсті ПРО АВтоРів / АвоUт тHE AUTHORS}

Чалий Сергій Федорович - доктор технічних наук, професор, професор кафедри інформаційних управляючих систем, Харківський національний університет радіоелектроніки, Харків, Україна;

Serhii Chalyi - Doctor of Technical Sciences, Professor, Professor of Professor of Information Control Systems Department, Kharkiv National University of Radio Electronics, Kharkiv, Ukraine;

e-mail: serhii.chalyi@nure.ua; ORCID ID: http://orcid.org/0000-0002-9982-9091.

Лещинський Володимир Олександрович - кандидат технічних наук, доцент, доцент кафедри програмної інженерії, Харківський національний університет радіоелектроніки, Харків, Україна;

Volodymyr Leshchynskyi - Candidate of Technical Sciences, Associate Professor, Associate Professor of Software Engineering Department, Kharkiv National University of Radio Electronics, Kharkiv, Ukraine; e-mail: volodymyr.leshchynskyi@ nure.ua; ORCID ID: http://orcid.org/0000-0002-8690-5702. 
Ієрархічна модель каузальних зв'язків для деталізації пояснень в інтелектуальних системах

С. Ф. Чалий, В. А. Лещинський

Анотація. Предметом вивчення в статті є процеси побудови пояснень в інтелектуальних системах на основі використання каузальних залежностей. Метою $є$ розробка ієрархічного представлення каузальних зв'язків між діями інтелектуальної системи для формування пояснення щодо опису процесу роботи системи із заданим ступенем узагальнення або деталізації. Представлення ієрархії причинно-наслідкових зв'язків дає можливість сформувати пояснення на заданому рівні деталізації з використанням вхідних даних у вигляді темпорально упорядкованої послідовності подій, що відображають відомі дії інтелектуальної системи. Завдання: структуризація ієрархії причинно-наслідкових залежностей для відомих варіантів процесу прийняття рішення в інтелектуальній інформаційній системі 3 урахуванням темпоральної упорядкованості відповідних дій; розробка моделі багаторівневого представлення каузальних залежностей для опису для пояснень в інтелектуальній системі. Використовуваними підходами $€$ : контрфактичний аналіз каузальності, який застосовується для опису альтернативних залежностей для можливих варіантів процесу прийняття рішення; лінійна темпоральна логіка, яка дає можливість відобразити темпоральний аспект каузальності. Отримані наступні результати. Виділено узагальнену ієрархію причинно-наслідкових залежностей для відомих варіантів процесу отримання рекомендацій в інтелектуальній інформаційній системі на основі темпоральної упорядкованості відповідних дій 3 прийняття рішення. Розроблено модель багаторівневого представлення каузальних залежностей для опису для по яснень в інтелектуальній системі із заданим ступенем деталізації. Висновки. Наукова новизна отриманих результатів полягає в наступному. Запропоновано модель ієрархічного представлення упорядкованих у часі причинно-наслідкових залежностей для опису пояснень щодо роботи інтелектуальної системи із заданим ступенем деталізації. На верхньому рівні ієрархії модель визначає узагальнений каузальний зв'язок між подією використання вхідних даних та подією отримання результату роботи системи. Даний зв'язок визначає поточну задачу, яку вирішує інтелектуальна інформаційна система. На нижньому рівні задаються причинно-наслідкові залежності між послідовними в часі подіями, між якими не існують інші події. На проміжних рівнях ієрархічного представлення визначаються каузальні залежності для пар подій, між якими є інші події. Розроблена модель створює умови для побудови пояснень із заданим ступенем деталізації дій процесу прийняття рішення в інтелектуальній системі. Також модель забезпечує можливість опису раннього та пізнього випередження для альтернативних послідовностей виконання процесу прийняття рішення шляхом опису каузальних залежностей для подій, між якими є інші події.

Ключові слова: інтелектуальна система; пояснення; контрфактичний аналіз,; каузальність; причиннонаслідковий зв'язок; темпоральна логіка.

\section{Иерархическая модель каузальных связей для детализации пояснений в интеллектуальных системах}

С. Ф. Чалый, В. А. Лещинский

Аннотация. Предметом исследования в статье являются процессы построения объяснений в интеллектуальных системах на базе использования каузальных зависимостей. Целью является разработка иерархического представления каузальных связей между действиями интеллектуальной системы для формирования объяснения процесса работы системы с заданной степенью обобщения или детализации. Представление иерархии причинно-следственных связей позволяет сформировать объяснение на заданном уровне детализации с использованием входных данных в виде темпорально упорядоченной последовательности событий, отражающих известные действия интеллектуальной системы. Задания: структуризация иерархии причинно-следственных зависимостей для известных вариантов процесса принятия решения в интеллектуальной информационной системе с учетом темпоральной упорядоченности соответствующих действий; разработка модели многоуровневого представления каузальных зависимостей для описания для пояснений в интеллектуальной системе. Используемыми подходами являются: контрфактический анализ каузальности, применяемый для описания альтернативных зависимостей для возможных вариантов принятия решения; линейная темпоральная логика, позволяющая отразить темпоральный аспект каузальности. Получены следующие результаты. Выделена обобщенная иерархия причинноследственных зависимостей для известных вариантов процесса получения рекомендаций в интеллектуальной информационной системе на основе темпоральной упорядоченности соответствующих действий по принятию решения. Разработана модель иерархического представления каузальных зависимостей для описания объяснений в интеллектуальной системе с заданной степенью детализации. Выводы. Научная новизна полученных результатов состоит в следующем. Предложена модель иерархического представления упорядоченных по времени причинноследственных зависимостей для описания объяснений работы интеллектуальной системы с заданной степенью детализации. На верхнем уровне иерархии модель определяет обобщенную каузальную связь между событием использования входных данных и событием результата работы системы. Данная связь описывает текущую задачку, которую решает интеллектуальная информационная система. На нижнем уровне задаются причинно-следственные зависимости между последовательными во времени событиями, между которыми не существуют другие события. На промежуточных уровнях иерархического представления определяются каузальные зависимости пар событий, между которыми есть другие события. Разработанная модель создает условия для построения пояснений с заданной степенью детализации действий процесса принятия решения в интеллектуальной системе. Также модель обеспечивает возможность описания раннего и позднего опережения альтернативных последовательностей выполнения процесса принятия решения путем описания каузальных зависимостей для событий, между которыми есть другие события.

Ключевые слова: интеллектуальная система; объяснение; контрфактический анализ; каузальность; причинноследственная связь; темпоральная логика. 